\title{
Sub Bottom Profiler Data Analysis to Identify the Thickness of Sediments (Study Case: Alur Pelayaran Timur Surabaya)
}

\author{
M. Dwiki Amirullah, Khomsin, and Danar Guruh Pratomo
}

\begin{abstract}
One of the acoustic instruments were used for the measurement of the seabed is the Sub Bottom Profiler. This instrument uses a low-frequency acoustic signal which has the ability to penetrate the layers of the ocean bottom up to a depth of several meters. The purpose of the survey using the Sub Bottom Profiler that is to conduct the investigation and identification of coating the ocean floor so that the retrieved information related to seabed stratigraphy. The location of research are on Alur Pelayaran Timur Surabaya. Secondary data is Raw data Sub bottom profiler, RAW data of single beam, SVP and tide data has been processed. The data retrieved from the District Navigasi kelas 1 Surabaya. The location of the research is classified as waters of the shallow waters. There are three layers of sediment. The pattern of seismic reflection data are parallel and subparallel. Thickness between the base of the sea surface with the first layer has a constituent sediments form the sandy mud. Thickness of the layer of sediment volume values the greatest there is between the first and second layers of $8.009 .815 .18 \mathrm{~m}^{3}$. The total volume of the thickness of the layer sediment 17,945,928.40 $\mathrm{m}^{3}$.
\end{abstract}

Keywords-Sub bottom profiler, sediment, thickness.

\section{INTRODUCTION}

Bathymetry survey is the process of mapping the waters, starting from the basis of measurement, processing, and visualization of the aquatic base [1]. The morphology of the sea floor is part of the panorama of the surface of the sea with regard to geological processes in the formation and development. Based on bathymetry map of Indonesia, a growing pattern of bathymetry shows the morphology of the sea floor following the coastline and the pattern of tectonic results [2]. Information on bathymetry and morphology of the sea floor is used for subsequent planning and consideration in determining a safe cruise lines.

Alur Pelayaran Barat Surabaya (APBS) is the Groove cruise that linked ships that will be docked at the port of Tanjung Perak of the Java Sea. While the Groove Cruise East Surabaya (APTS) is connecting ports in the port with the APBS in East Java among other ports of Pasuruan, Probolinggo, Panarukan, Kalbut, Branta, Kalianget, and Banyuwangi and Ports in the region Central and Eastern parts of Indonesia [3]. to do the development in this area, the basic water measurement is required.

In this study, sediment thickness analysis data was obtained from a survey Alur Pelayaran Timur Surabaya using Sub

M. Dwiki Amirullah, Khomsin, and Danar Guruh Pratomo are with Department of Geomatics Engineering, Institut Teknologi Sepuluh Nopember, Surabaya, 60111, Indonesia. E-mail: guruh@geodesy.its.ac.id. bottom profiler innomar SES 2000 light plus. Survey singlebeam ecosounder is also conducted to determine depth accurately because the measurment of the bathymetry using SBP does not comply with the required standards based on the IHO-2008 or SNI [4]. In addition, data processing survey results of Sub Bottom Profiler to obtain information.

The purpose of this research is to analyze data from SBP for further identification of sediment thickness. The results of this study are expected to be used as a reference in the development of security Alur Pelayaran Timur Surabaya area.

\section{MethodolOGY}

\section{A. Research Area}

The location of this research is waters of Alur Pelayaran Timur Surabaya, East Java,. Geographically location this research at coordinates $07^{\circ} 17^{\prime} 15.06^{\prime \prime} \mathrm{LS}$ and $112^{\circ} 50^{\prime} 48.84$ " BT to $07^{\circ} 23^{\prime} 30.98$ " LS and $112^{\circ} 58^{\prime} 03.45^{\prime \prime} \mathrm{BT}$, shown in Fig. 1.

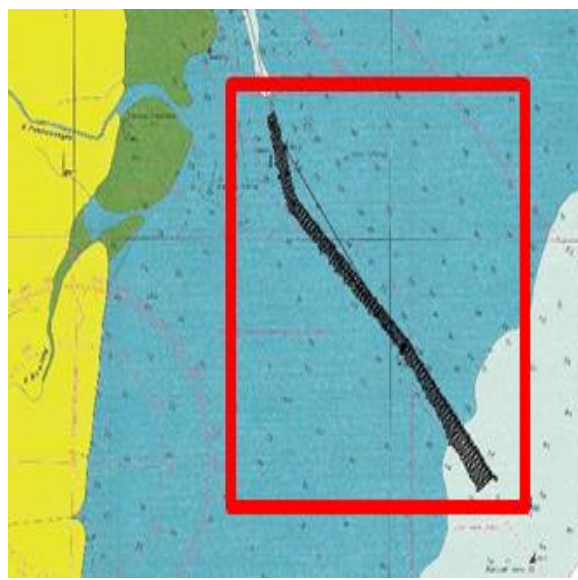

Figure 1. The Location of Research Area, Alur Pelayaran Timur Surabaya Chart Map (Pushidrosal).

So UTM projection system used is zone $49 \mathrm{~S}$, with units of measure used to stated coordinates (x,y), depth (z), and other aspects are meters $(\mathrm{m})$.

\section{B. Tools and Data Acquisition}

In this research used spatial and hydro-seismic data. The spatial data include Chart Map (Surabaya- APBS and APTS) 2016. While hydro-seismic data include:RAW data bathymetry, RAW data SBP,tidal elevation data was processed, SVP data, and sediment sample. In order processing and analysis this research utilizes software: 
a. Surfer as software for $3 \mathrm{~d}$ modelling.

b. ArcGIS 10.3 for process layouting on screen.

c. Hypack, for processing RAW data bathymetry and RAW data SBP.

d. Innomar converter 2.0 for convert format file SBP.

\section{Methods}

1) Make a map of the bathymetry.

At this stage the depth of measurement results in the correction with the tidal waters survey data and data speed of sound in water (SVP) so the obtained data corrected depth. Bathymetric data was corrected in interpolation to get depth contour. At this stage the bathymetry data in ploting according existing coordinates on a map. After that the data presented in the map.

2) Convert .SES data (SBP data) to .sgy data.

The SES data obtained from the SBP tool is then converted to a data format to be processed to obtain the data of sediment thickness.

3) Geometric and Input Parameter.

The geometry is define coordinates are shot point. This information is very important, so that the stage of the geometry has to do more careful. The input Parameter is the process of entering the parameters to get the value of the depth of the rectified. Parameters that included covering the value tides and SVP.

4) Radiometric corection.

The sgy data that has been obtained is then corrected radiometrically to smooth the $2 \mathrm{~d}$ view of the seismic data.

5) Dynamic Range.

The usefulness of this step is to refine the range of light intensities ranging from darkest to brightest highlights, shadow and smooting on data.

6) Interpretation Of The Data.

Interpretation of data is used to determine the baseline of the water surface and determine the thickness of the sediment layer as well as the reflection pattern. In this study conducted a qualitative interpretation, namely by making horizon withdrawal to obtain depth of waters and sediment deposition limits.

7) Interpretation Of The Data.

Interpretation of data is used to determine the baseline of the water surface and determine the thickness of the sediment layer as well as the reflection pattern. In this study conducted a qualitative interpretation, namely by making horizon withdrawal to obtain depth of waters and sediment deposition limits.

\section{RESULT AND DISCUSSION}

\section{A. Bathymetry map}

RAW data singlebeam, tidal data and sound velocity profiler data obtained through surveys conducted by District Navigation Surabaya processed to obtain the topography of the sea floor. RAW data amounts to 179 data where one data contains one survey path so that the total survey path is processed 179 survey lines. The research area is $276,891 \mathrm{~m}^{2}$ with total area $10,033.42 \mathrm{~m}$.

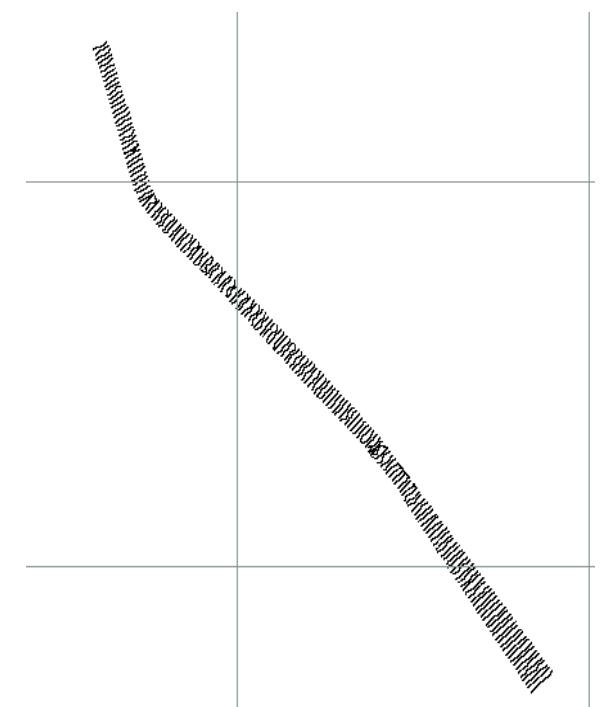

Figure 2. The Results of The Survey The Bathymetry Data Line Display.

Correction of the single beam depth value is done by inserting the sound velocity profiler and the tide values to the vertical datum lws. The value of the bathymetry that has been rectified in interpolation and ploting into the map of the sea. Contour map of the bathymetry Alur Pelayaran timur Surabaya has small contour density due to variations in the value of the depth of the research area. It can be seen from the depth values ranged from 2.43 to $5.95 \mathrm{~m}$ from lws. So the location of the research can be categorized as shallow waters. The information of waters depth indicated by contour of color gradation, with value of depth from 0 up to 25 meters. The deepest area in the sea, with a depth value of 20 up to 25 meters indicated by red color. While in the area of Jetty, depth value ranges between 2 up to 10 meters with color gradations of blue.

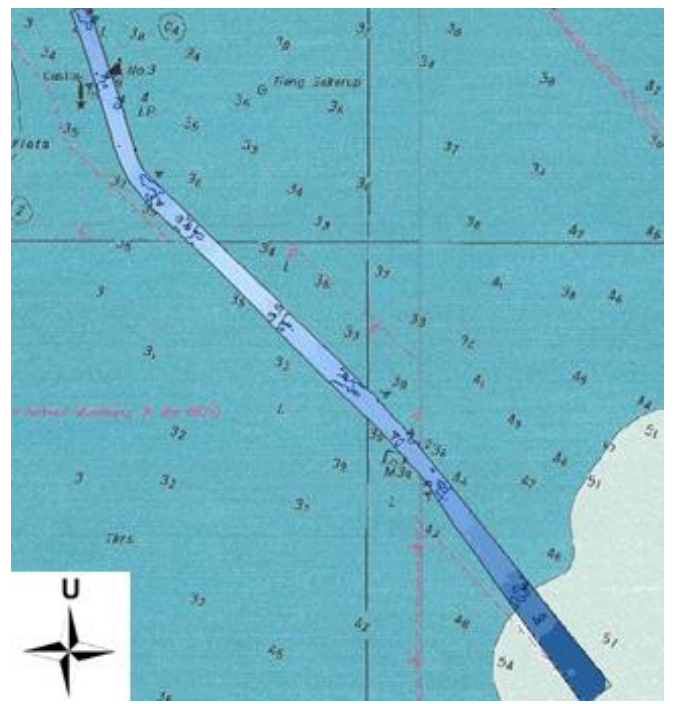

Figure 3. The Results of The Bathymetry Data View That Has Been Plotting. 
The $3^{\text {rd }}$ Geomatics International Conference 2018

July $12^{\text {th }} 2018$, Institut Teknologi Sepuluh Nopember, Surabaya, Indonesia

Presentation of data enhanced by doing layouting on a map by including information that consists of the value of the position and the value of depth.

\section{B. Sub Bottom Profiler Analysis}

Before the data is processed the data is converted from the .SES data format to the .SGY data format. Further data is entered together with other data parameters such as tidal data and SVP data into the processing software. Application of correction is done to clarify the display of data so as to facilitate the drawing of the layer boundary. The results of SBP data processing include application of bottom tracking and auto range correction and radiometric correction including the application of Time Varying Gain correction. Based on the SBP data shown on the SBP cross-section image.

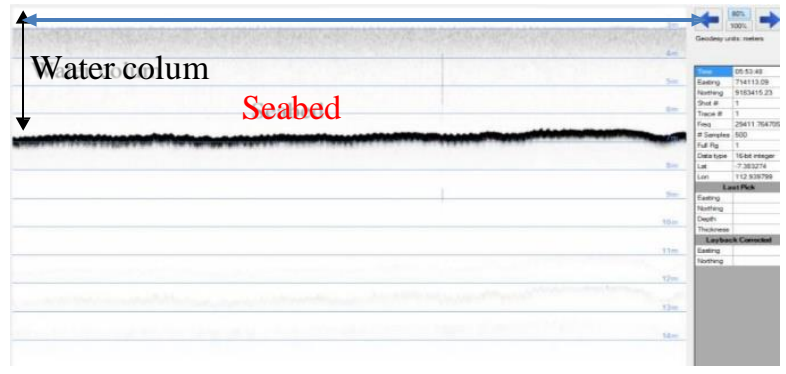

Figure 4. Results of SBP Data Input.

At the beginning of the process done the correction Auto range and bottom tracking to clarify the distance between the water column with the surface of the sea floor and eliminate beam wave in the water column. Bottom tracking process also produces the base line underwater survey along the path. TVG correction done to unify some of the trace to a specific trace to become one and also for doing the smooting on data. TVG correction also serves to improve the quality of the data view.

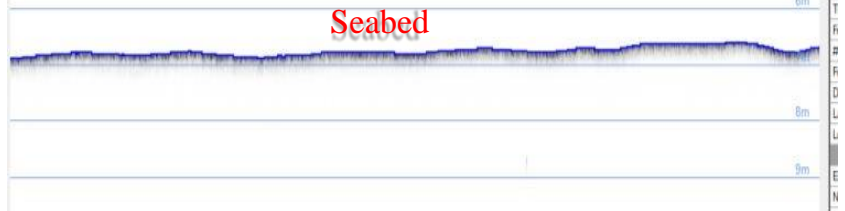

Figure 5. Results Correction Auto Range, Bottom Tracking, and TVG.

The next process i.e. clarify the data view by improving the range of light intensities ranging from darkest to brightest shadows. This process is called dynamic range. On the process of dynamic range is done by changing the color of the data display and change the density of the data so that the color contrast differences will be seen very clearly. The result of the process of dynamic range can be seen in Fig. 6 .

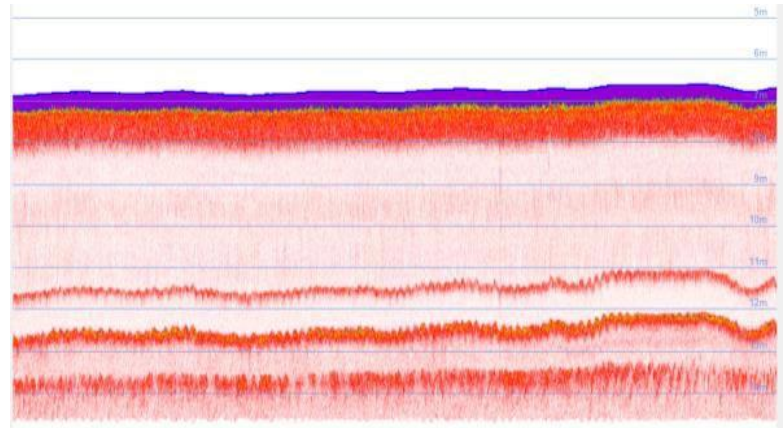

Figure 6. The results of the process of Dynamic Range to Data SBP.

Based on the theory of reflectivity, contrasting colors clearly show the thickness of the boundary layer. Interpretation of the data is done by creating a boundary line between the contrast of different colors. The creation of the boundary layer is done by means of appropriate forms of digitizing a line sloping sea floor coating.

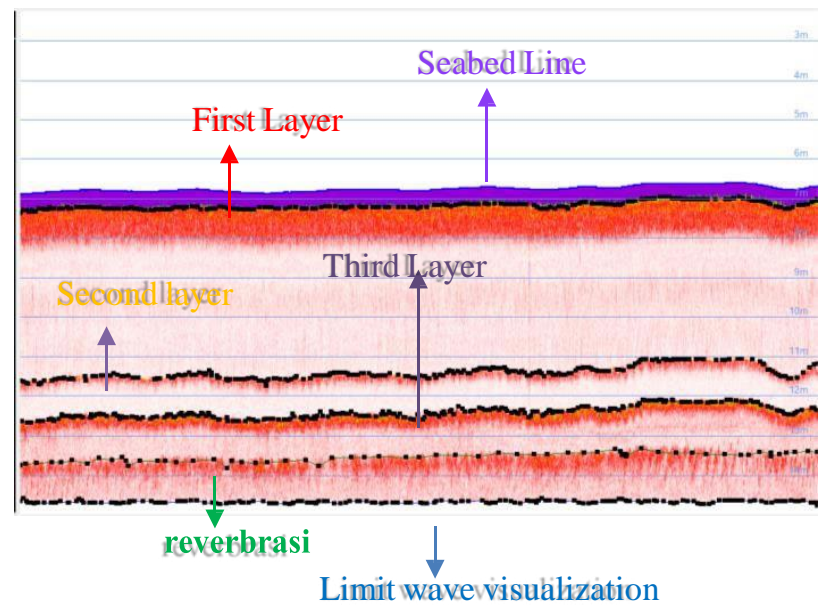

Figure 7. Correlation of Observation Tide and Model Tide Data

In addition to clarify the boundaries of polygons, can be done with color on the boundary between layers. But the coloring area thickness can only do a maximum of 3 layer limit. To observe the results of digitation and coloring areas could do with a fence diagram. Fence diagram is description of cross- section data from each row of the SBP. Following the result of the colorization and sediment thickness area in fence diagram.

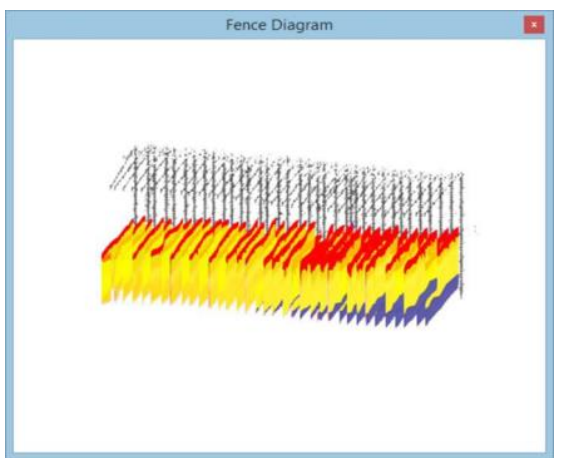

Figure 8. Fence Diagram. 
Results tracking and bottom layer of the ocean floor next digitazion is stored in the form xyz file then do interpratation process data. Interpretion results between layers are described as follows:

a) The base of the sea level.

The results of the depth of the sea floor bottom tracking has a value between $2.68 \mathrm{~m}$ to $5.09 \mathrm{~m}$ vertical datum of lws. The length of the path the seabed of $10,033.42 \mathrm{~m}$.

b) First Layer.

The results of the digitazion layers of sediment between the depth value is first $3.37 \mathrm{~m}$ up $5.79 \mathrm{~m}$ of vertical datum lws and has the same path length that is $10,033.42 \mathrm{~km}$. This show that all tracks the path of having the first layer.

c) Second layer.

The result of the digitization of the second sediment layer has a depth value between $5.8 \mathrm{~m}$ to $10.91 \mathrm{~m}$ of the lws vertical datum and has a trajectory length of $9,071.89 \mathrm{~m}$. This shows that not all trajectories have a second layer. There are 16 track paths that do not have a second layer. This is because when the visualization is done, the second layer is outside the visual boundary line of wave propagation so that digitization can not be done.

d) Third Layer.

The result of the digitization of the third sediment layer has a depth value between $6.93 \mathrm{~m}$ to $11.92 \mathrm{~m}$ of the lws vertical datum and has a trajectory length of $8,997.33 \mathrm{~m}$. This shows that the third layer is not present on the entire lane path. There are 35 lane paths that do not have a third layer. This is because when the visualization is done, the second layer is outside the boundary line of wave velocity visualization so that digitization can not be done.

In addition to determining the boundary layer, Interpretation is done by observing the seismic reflection pattern on the layer cross section image. To determine the pattern of seismic reflection, do band pass filtering. From the result of filtering band pass, known that the seismic reflection pattern in this configuration is parallel until subparallel. This is show with the pattern of the reflection amplitude has a parallel, uniform continuity, as well as the existence of basin and time separation are stable. Levels of the lateral variation shows the level of changes in local precipitation and speed litologinya. The existence of a similarity reflection patterns on the first layer to third layer proved that the sediments between layers have the same pattern [5].

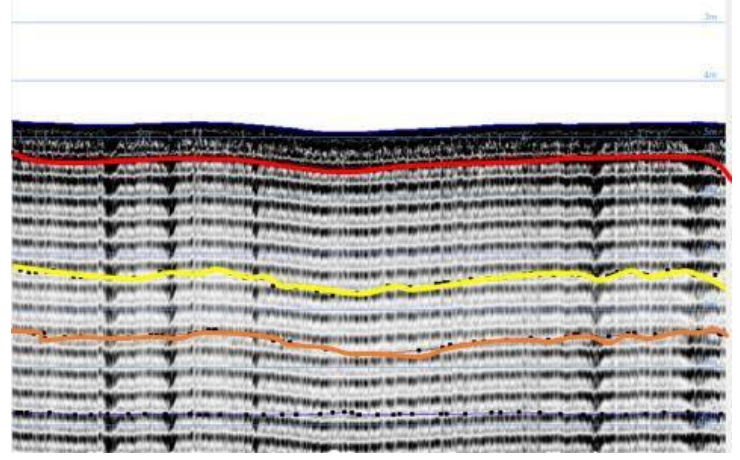

Figure 9. Band Pass Filtering.
Thereafter, 3-dimensional modeling of all lanes that has been digitized per layer to determine the thickness of the sediments. The modeling results are shown by the Fig. 10.

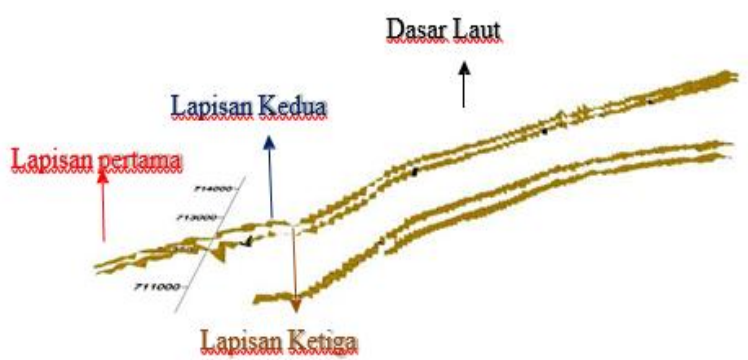

Figure 10. The Results Of Modeling Of The Sedimentary Thickness Between The Base Of The Lower Surface.

3D modeling performed between seabed tracking the data bottom dwngan first sediment layers, the first layer and the second layer, and the second layer with the third layer. 3D modeling performed by the nearest neighbor method.

To find out the thickness of the sediment volume, volume calculations done with compositing method. Calculation of the thickness of the sediment volume was done between the surface of the sea floor with the first layers, the first layer with a second layer, a second layer with a third layer, as well as a third layer with visualization creep wave.

TABLE 1.

The Volume Of Sediment THICKNess BeTween LAYERS

\begin{tabular}{clc}
\hline \hline $\begin{array}{c}\text { Thickness } \\
\text { Number }\end{array}$ & Layer Thickness & Volume $\left(\mathbf{m}^{3}\right)$ \\
\hline 1 & Seabed surface with the first layer & $1,638,618.46$ \\
2 & First layer with Second layer & $8,009,815.18$ \\
3 & Second layer and Third layer & $2,665,328.73$ \\
4 & $\begin{array}{l}\text { The three layers with visualization limits } \\
\text { propagation }\end{array}$ & $5,632,166.03$ \\
\hline \hline
\end{tabular}

To find out the constituent sediments on the respective layer thickness, the taking of the sample and the interpretation of sediment thickness.

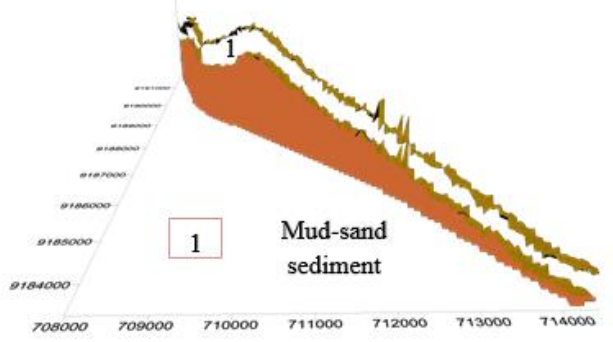

Figure 11. The Thickness of Sediment Between the Seabed Surface with The First Layer.

Sediment samples were taken only on the basis of the sea level so that the thickness of the sediments of known sedimentary field test of constituting only the layer sediments .between the base of the sea surface with the first layer. In addition the results of the interpretation of the image of the side scan sonar also showed that most of the base surface is dominated by Sandy sediment. The taking of the sample until 
The $3^{\text {rd }}$ Geomatics International Conference 2018

July $12^{\text {th }} 2018$, Institut Teknologi Sepuluh Nopember, Surabaya, Indonesia

the bottom layer (coring) was not done when the survey Alur Pelayaran Timur Surabaya area because of the limitations of the tool.

\section{CONCLUSION}

The research activities of sub bottom profiler data analysis for the identification of sediment thickness produces the following conclusion:

a. The location of research is classified as the waters of the shallow waters. It can be seen from the depth values ranged from 2.43-5.95 $\mathrm{m}$ from lws.

b. There are three layers of sediment. Seismic reflection patterns on the configuration data are parallel and sub pararell. Thickness between the base of the sea surface with the first layer has a constituent sediments form the sandy mud. Thickness of the layer of sediment volume values the greatest there is between the first and second layers is $8,009,815.18$ $\mathrm{m}^{3}$. The total volume of the thickness of the layer of sediment $17,945,928.40 \mathrm{~m}^{3}$.

\section{ACKNOWLEDGEMENT}

The authors give thanks to Distrik Navigasi Kelas 1 Surabaya who has provided data and guidance during in this research.

\section{REFERENCES}

$[1]$

$$
\text { Aditama, } 2005 .
$$

Poerbandono and Djunarsjah, Survei Hidrografi. Bandung: Refika

M. Salahuddin, S. Lubis, A. Makmur, and P. Astjario, "Pangkalan data Geologi dan Geofisika Kelautan di Wilayah Perairan Indonesia," Bandung, 2001.

[3] H. Setyobudi, "KEMENHUB Integrasikan 2 (Dua) Alur Pelayaran Surabaya," Jakarta, 2017.

[4] M. Afif, "Analisis Ketelitian Data Sub Bottom Profilers Untuk Pengukuran Kedalaman Permukaan Dasar Laut," Yogyakarta, 2017.

[5] Silean, "Interpretasi Struktur Bawah Permukaan Berdasarkan Data Seismik 2d untuk Perhitungan Manual Gross Rock Vokume Reservoal pada Lapangan,” Lampung, 2015. 